\title{
KÄYTÄNNÖLLISEN TIEDON HAASTEET TIETOTEKNIIKALLE JA KOULUTUKSELLE
}

Göranzon, B. 1990. Det praktiska intellektet. Datoranvändning och yrkeskunnande. Stockholm: Carlssons.

Ruotsalaisen työelämän vaikuttajan, Arbetslivscentrumin tutkijan, Bo Göranzonin väitöskirja vetää yhteen johtopäätöksiä vuosina 1977-1989 toteutetusta tutkimusprojektista 'Koulutus - työ - teknologia'. Projektissa suuntauduttiin toisaalta tietoteknisten ratkaisujen suunnitteluun sekä toisaalta tietojenkäsittelyn ja ammattipätevyyden yhteyksien hahmottamiseen erityyppisiä tapaustutkimuksia hyödyntäen.

Projektin eri vaiheissa on julkaistu erilaisia raportteja ja kirjoja sekä järjestetty useita konferensseja ja seminaareja. Lähdeluettelosta löytyy viittauksia yksin Göranzonin kohdalta 33 lähteeseen, puhumattakaan viittauksista muuhun projektin puitteissa tehtyyn tutkimukseen. Tämä arvio on laadittu tutustumatta, muuhun projektissa tuotettuun materiaaliin ja niin ollen kohdistuu ainoastaan tähän Göranzonin teokseen.

Göranzonin teos ei vähimmässäkään määrin muistuta tieteellistä opinnäytettä. Se on kansantajuisesti kirjoitettu ja argumentoiva. Göranzon antaa tilaa käytännön työntekijöille (tutkimuksen informanteille) ja muille tutkijoille, joiden argumentit hän on pyrkinyt rakentamaan dialogin muotoon. Tämä tekee teoksesta helposti luettavan, mutta samalla varsin pinnallisentuntuisen. Pinnallisuudentuntua lisää se, että hän jättää huomiotta useat samoihin kysymysasetteluihin suuntautuneet tutkijat ja heidän julkaisunsa.

Göranzonin keskeinen argumentti on rakennettu käytännöllisen ja abstraktin tiedon vastakkainasettelulle. Tämä vastakkainasette- lu etenee läpi koko teoksen sekä tapaustutkimusten että filosofisen pohdiskelun kautta. Käytännöllinen tieto on rakentunut toiminnan ja sen kautta kerättyjen kokemusten perustalle ja sellaisena on yleensä piilevää tietoa, jota ei voida julkilausua, mutta joka muodostaa ammattipätevyyden perustan. Abstrakti tieto puolestaan nivoutuu tieteellisen vallankumouksen pyrkimykselle löytää säännönmukaisuuksia todellisuudesta ja rakentaa täsmällinen ja yksiselitteinen kieli näille säännönmukaisuuksille.

Metsätyönjohtajia ja vakuutusvirkailijoita koskevien tapaustutkimusten avulla Göranzon osoittaa, miten tietotekniikan esiinmarssi työpaikalla itse asiassa muodostaa uhan ammattipätevyydelle. Ammattipätevyys nähdään käytännölliseen tietoon perustuvana, tietynlaisena näppituntumana, jossa metsätyönjohtajien kyky laskea manuaalisesti liittyy aivan olennaisesti kykyyn arvioida laskelmien tuloksia ja tehdä johtopäätöksiä. Samoin vakuutusvirkailijoiden kyky selvittää asiakkaille tehtyjä korvauspäätöksiä on sidoksissa asioiden rutiininomaisen käsittelyn hallintaan.

Työpaikoille esitellyt tietojärjestelmät puolestaan pyrkivät rationalisoimaan työtä rakentamalla normatiivisen sääntöihin perustuvan systeemin, joka paitsi alentaa pätevyysvaatimuksia myös lisää epävarmuutta tehtyihin johtopäätöksiin. Tietokoneet eivät näin ollen ole ainoastaan 'työkaluja' rutiininomaisten operaatioiden hallitsemiseksi. Ne ovat yhtä lailla 'toimintaa ohjaavia koneita', jotka määräävät, miten työtä tehdään. Onkin ymmärrettävää, että metsätyönjohtajat eivät itse suostuneet mokomiin koneisiin 
koskemaan, vaan pistivät apulaisensa asialle. Syntyi uusi ammattiluokka metsätyönjohtajien ja tietojärjestelmän kehittäjien väliin, jolla ei oikeastaan ollut riittävää tietoa kummaltakaan alueelta.

Göranzon liittää ammattipätevyyden nimenomaan käytännölliseen tietoon ja näkee, että se on kokemusten kautta rakentunutta, tilannesidonnaista, henkilökohtaista ja julkilausumatonta. Hän jopa esittää, että käytännöllisen tiedon julkilausuminen ja käytännön toimintaohjeiden rakentaminen tältä pohjalta johtaa huonompiin tuloksiin kuin kokemusperäinen ja intuitiivinen näppituntumalta toimiminen. Hän näkee vaaraksi sen, että konkreettinen suhde todellisuuteen häviää ja työntekijät käsittelevät vain abstrakteja malleja todellisuudesta.

Hänen loppukaneettinsa painottaakin, että " kriittisintä puolta inhimillisessä toiminnassa ei voi ymmärtää analyyttisesti, kuten esimerkiksi, fysiikan lakeja, vaan inhimillisen dimension tavoittaminen edellyttää esteettistä näkökulmaa"' (s. 170).

Koulutukseen suuntautuva keskustelu jää teoksessa varsin vähälle. Selväksi kuitenkin käy, että käytännöllisen tiedon korostuminen ammattipätevyyden perustana johtaa perinteiseen oppipoikajärjestelmään, jossa pätevyys saavutetaan tekemällä asioita käytännössä. Tällöin esimerkiksi rutiininomaisten manuaalisten laskutoimitusten opetteleminen on välttämätöntä, jotta voisi kokonaisvaltaisesti hallita toimintaansa.

Toisaalta hän esittää myös, että filosofian, kirjallisuuden ja historian opiskelu kuuluu olennaisena osana $\mathrm{mm}$. insinöörien koulutukseen. Näin työ opittaisiin näkemään myös humaanista perspektiivistä.

Kaiken kaikkiaan Göranzon tuntuu näkevän maailman varsin musta-valkoisena. Konkreettinen ja abstrakti muodostuvat toistensa vastakohdiksi ja kritiikki tietotekniikkaa ja sen sovellutuksia kohtaan muodostuu konkreettisen puolustukseksi ja abstraktin vastustukseksi. 'Tämän vastakohtaisuuden ylittäminen jää haaveeksi - osittain varmaankin siksi, että varsinainen tietoteoreettinen ja tiedonsosiologinen keskustelu loistaa poissaolollaan. Göranzonin argumentit tuntuvat enemmän heitoilta kuin systemaattisilta ja tieteellisiltä perusteluilta. Tämäkin ehkä heijastaa uskoa juuri käytännöllisen tiedon voimaan.

On myös yllättävää, että itse käytännöllisen tiedon käsite jää Göranzonin teoksessa syvemmin analysoimatta, huolimatta siitä, että se on ollut viime aikoina sekä pskykologien että sosiologien mielenkiinnon kohteena.

Koulutuksen suuntaan eivät teoksessa esitetyt suuntaviivat juurikaan pure. Perinteinen työssä oppiminen ja koulutuksessa oppiminen asettuvat vastakkain, ja Göranzon asettuu puolustamaan työssäoppimista oppipoikajärjestelmään perustuen. Työntekijöiden käytännön kautta rakentama tapa toimia on siis ylivertainen koulutuksessa tuotettuun verrattuna. Tarkoittaako tämä sitä, että koulutusta ei tulisikaan järjestää? Tähän kysymykseen Göranzon ei vastaa.

Jää myös epäselväksi, miten muutokset työkäytännöissä, teknologiassa ja yleensä yhteiskunnassa nivoutuvat osaksi käytännöllistä tietoa. Esitettyjen tapausten perusteella työntekijät kokevat muutokset uhkaavina ja epävarmuutta lisäävinä. Mutta merkitseekö tämä, että muutoksia tulisi vastustaa?

Miten käytännöllinen tieto muuttuu ja kehittyy? Millaisia vaatimuksia tämä asettaa tietojärjestelmien ja työkäytäntöjen kehittäjille? Tuntuu siltä, että teoksessa ei päästä näihin koulutuksen kannalta keskeisiin kysymyksiin lainkaan kiinni.

Kritiikistä huolimatta Göranzonin teos oli miellyttävää ja ajatuksia herättävää luettavaa. Väitöskirjaksi sitä ei uskoisi, pikemminkin keskustelunavaukseksi. Sellaisena se toimiikin hyvin. 